\title{
THE EFFECT OF GYMBALL TECHNIQUE ON THE DECREASE OF THE LOWER FEET IN PRIMIGRAVIDA TRIMESTER III MOTHERS
}

\author{
Sri Hadi Sulistiyaningsih ${ }^{1}$, Siti Niamah² \\ 1Program Studi Sarjana Kebidanan STIKes Bakti Utama Pati \\ 2Program Studi Diploma Tiga Kebidanan STIKes Bakti Utama Pati
}

mahira.hsp@gmail.com, Sni39amah@yahoo.co.id

Submitted : 7 January 2022 . Accepted : 28 February 2022 . Published : 10 March 2022

\begin{abstract}
A gymball is a physical therapy ball that helps pregnant women in lowering the baby's head that can be used in various positions. One of the movements is by sitting on the ball and rocking to make a sense of comfort and help lower the baby's head using gravity while increasing the release of endorphins because the elasticity and curvature of the ball stimulate the receptors in the pelvis that are responsible for secreting endorphins. The purpose of this study was to determine the effect of the gym ball technique on the decrease in the lower part of the fetus in thirdtrimester primigravida mothers. This research is pre-experimental design research with a one-group pretest-posttest design. The research sample was 10 primigravida third trimester 32 weeks pregnant women using the total sampling technique. The analytical test used is the paired t-test. Based on the paired t-test statistical test, it was found that $p$ value $=0.000$ with a significant value $=0.05$ because $p<0.05(0.000<0.05)$ it can be concluded that there is an effect of the gym ball technique on the decrease in the lower part of the fetus in the mother. third trimester primigravida. It is hoped that the gym ball technique can be used as a good and safe exercise choice for pregnant women to improve physical health, reduce anxiety and help the process of lowering the fetal head.
\end{abstract}

Keywords: Gym Ball, Lower fetal descent, Primigravida

\section{BACKGROUND}

Pregnancy is something that every mother will experience. The process of pregnancy can run normally, but in the process, there can be various problems that can harm the mother and fetus. The problems faced can be in the form of mild problems which are the result of physiological changes of pregnant women to severe problems that become pregnancy complications. The problems faced by pregnant women can occur in any period of pregnancy, from the first trimester to the third trimester. The process of pregnancy to birth is a series in one unit starting from conception, nidation, the introduction of maternal adaptation to nidasi, maintenance of pregnancy, endocrine changes as preparation for the birth of a baby, and childbirth as readiness to care for a baby. Pregnancy causes change both anatomical and physiological in the mother. In pregnancy, there is an adaptation of the mother in physical and psychological forms (Purwati, 2020).

Changes due to pregnancy are experienced by the entire woman's body, starting from the digestive, cardiovascular, and musculoskeletal systems. The gradual change in the body from the increase in the weight of the pregnant woman causes the posture and gait of the woman to change. Increased abdominal distension which makes the pelvis tilt forward, decreased abdominal muscle tone, and the center of gravity shifts forward so that there is a tendency for the waist muscles to shorten if the abdominal muscles are stretched causing an imbalance of the pelvic muscles which can cause discomfort in the lower waist and also have an impact on baby's head drop (Prawiroharjo, 2018).

The head of the fetus that has entered the pelvic inlet is a sign of the onset of labor. Generally, the fetal head enters the pelvic inlet (PAP) at the end of gestation. In primigravida, the fetal head enters the pelvic inlet at 36 weeks of gestation. According to Kohar in Sitohang (2021), the entry of the fetal head in the pelvic inlet occurs at 38 weeks of gestation. After the inclusion of the fetal head on the PAP, labor is expected to begin 2-3 weeks. Based on the traditional concept, in primigravida, the entry of the fetal head into the pelvic cavity occurs at 38 weeks of gestation. 
However, it is not following a clinical practice. In general, the entry of the fetal head into the pelvis occurs between 38-42 weeks or even during the first stage of labor (Sihotang, 2021).

In Bobak (2007) various methods to overcome discomfort due to physical changes that occur during pregnancy can be done both pharmacologically and non-pharmacologically. Pharmacological methods have the potential to cause adverse side effects for both mother and fetus. Meanwhile, non-pharmacological methods tend to be easier and safer to give to mothers. These non-pharmacological methods include hypnosis, acupressure, yoga, therapeutic touch, aromatherapy, relaxation, listening to music, warm compresses, cold compresses, and the use of Gym balls (Kurniawati et al., 2017).

A gym ball is a physical therapy ball that helps pregnant women in lowering the baby's head that can be used in various positions. One of the movements is by sitting on the ball and rocking to make a comfortable feeling and help lower the baby's head using gravity while increasing the release of endorphins because the elasticity and curvature of the ball stimulate receptors in the pelvis which are responsible for secreting endorphins (Kurniawati et al., 2017).

According to Souza, J.P (2016), the birth ball is one of the active birth methods that can be used during the first stage of labor. A birth ball is a physical therapy ball that helps pregnant women in the first stage of labor into a position that can help labor progress. A physical therapy ball can be used in a variety of positions. Sitting on the ball and rocking makes you feel comfortable and makes labor progress using gravity while increasing the release of endorphins due to the elasticity and curvature of the ball, stimulating receptors in the pelvis to secrete endorphins (Darma \& Abdillah, 2020).

According to Aprilia's theory in Purwati's research (2020) in the labor process, the ball (birthing ball) can be a medium/tool to be used in various positions. Sitting on a ball while pushing like a swing or making pelvic rotational movements can help lower the fetus into the pelvic floor. The ball provides support to the perineum without too much pressure and helps speed up the delivery process. In addition, the advantage of sitting upright on the ball can increase blood flow to the uterus, placenta, and baby, this posture makes the force of gravity push the baby's head down (Purwati, 2020)

Research conducted in India by Sharma and Soni (1978), and Gosh and Chaudharin (1980) found that 50\% and $43.4 \%$ of primigravida with involvement of the fetal head in the pelvis was a sign of impending labor. This study was based on a prospective study of 176 randomly selected primigravida who performed antenatal clinic visits at Neyveli General Hospital, India. However, only 27 primigravidas from 36 to 42 weeks gestation with first head involvement were reported in the study. The results showed that at 34 and 35 weeks of gestation there was no reported data on the entry of the fetal head into the PAP and pelvic cavity, while at 36 weeks of gestation there were found the number of primigravida with the fetal head entering the PAP and pelvic cavity as much as 1 person and the prevalence was $3.70 \%$. and obtained the highest number of primigravida with fetal head entering the PAP and pelvic cavity as many as 8 people with a prevalence of $29.63 \%$ occurring at 40 weeks of gestation (Sihotang, 2021).

Research conducted by Purwati (2020) shows that of the 16 respondents before giving treatment using the birth ball technique, almost all 11 people (69\%) experienced a decrease in the lower part of the fetus in Hodge II and a small proportion of respondents as many as 1 person (6\%) in Hodge I. Meanwhile, after giving treatment using the birth ball technique, almost all 10 people (63\%) experienced a decrease in the lower part of the fetus in Hodge III and a small number of respondents as many as 6 people (37\%) ) at Hodge IV (Purwati, 2020).

Meanwhile, according to research from Indrayani, et al (2019), it is stated that the position of the mother also greatly influences the adaptation of the anatomy and physiology of childbirth. The upright position also provides several advantages. Changing positions provides comfort, reduces fatigue, and improves blood circulation. The upright position includes sitting on a gym ball (pelvic rocking), standing, squatting, walking. The upright position allows for lower fetal descent. Birthing balls also have other benefits, including reducing the incidence of the 
prolonged first stage, accelerating cervical dilatation, stimulating uterine contractions, widening the diameter of the pelvis, and accelerating the descent of the fetal head (Triana Indrayani, S.ST. \& Riyanti, 2019).

The purpose of this study was to determine the effect of the gymball technique on the lowering of the fetus in the third trimester of primigravida. This research is pre-experimental design research with a one-group pretestposttest design.

\section{METHOD}

This type of research is pre-experimental design research with a one-group pretest-posttest design. The scope of this research is included in the scope of maternal and child health. The independent variable is the Gym Ball Technique while the dependent variable is the Lower Fetal Decrease in the Third Trimester Primigravida Mother. The study was conducted in December 2020 - June 2021 at the Lydia Sifra Kudus Clinic. The samples in this study were pregnant women in the third trimester of 32 weeks pregnant, totaling 10 people with the lowest part of the fetus not yet entering the PAP with a cephalic presentation. The sampling technique used was total sampling. The instrument used is in the form of an observation sheet. Data processing is done by editing, coding, scoring, and tabulating data. Meanwhile, data analysis includes univariate and bivariate tests with paired t-tests.

\section{RESULT AND DISCUSSION}

\section{A. RESULT}

1. Univariate Analysis

Table. 1

Frequency Distribution of Respondents Characteristics

\begin{tabular}{clcc}
\hline No & \multicolumn{1}{c}{ Characteristics } & f & $\%$ \\
\hline 1. & Age (years) & & \\
& $\leq 20$ years & 2 & 20 \\
& $21-30$ years & 8 & 80 \\
& $>31$ years & 0 & 0 \\
2. & Education & & \\
& Primary school & 2 & 20 \\
& Junior High school & 3 & 30 \\
& High School & 5 & 50 \\
College tall & 0 & 0 \\
Work & & \\
& Housewife & 5 & 50 \\
& Private & 5 & 50 \\
& PNS & 0 & 0 \\
\hline
\end{tabular}

Table. 1 shows the characteristics of respondents based on age, namely the age group 20 years as many as 2 people (20\%), the age group $21-30$ years as many as 8 people $(80 \%)$, and the age group $>31$ years none $0(0 \%)$. The education level of the respondents was 2 people in elementary school $(20 \%), 3$ people in junior high school (30\%), 5 people in high school $(50 \%)$, and $0(0 \%)$ in PT. Types of work as housewives as many as 5 people $(50 \%)$, private sector as many as 5 people $(50 \%)$ and there are no universities $0(0 \%)$.

Table.2

Frequency Distribution of Lower Fetal Decline

Before the Implementation of Gym Ball on Third Trimester Primigravida Mothers

\begin{tabular}{lccc}
\hline \multicolumn{1}{c}{ Lower Fetal Decline } & Frequency & $\%$ \\
\hline $5 / 5$ (not entered PAP) & 10 & 100 \\
\hline $4 / 5$ (Hodge I-II) & 0 & 00 \\
\hline $3 / 5$ (Hodge II-III) & 0 & 0 \\
\hline
\end{tabular}




\begin{tabular}{lll}
\hline Quantity & 10 & 100 \\
\hline
\end{tabular}

Table. 2 shows that the lowest part of the fetus has not entered the pelvic inlet as many as 10 people $(100 \%)$ and the lowest part of the fetus has entered the pelvic inlet there are 0 people $(0 \%)$.

Table. 3

Frequency Distribution of Lower Fetal Decline After the Implementation of Gym Ball on the Third Trimester Primigravida Mothers

\begin{tabular}{lcc|}
\hline \multicolumn{1}{c}{ Lower Fetal Decline } & Frequency & $\%$ \\
\hline $5 / 5$ (not entered PAP) & 2 & 20 \\
\hline $4 / 5$ (Hodge I-II) & 3 & 30 \\
\hline $3 / 5$ (Hodge II-III) & 5 & 50 \\
\hline Quantity & 10 & 100 \\
\hline
\end{tabular}

Table. 3 shows that the lowest part of the fetus that has not entered the LAP as many as 2 people (20\%), the lowest part of the fetus has entered the pelvic inlet (Hodge I-II) as many as 3 people (30\%), and the lowest part of the fetus has entered the pelvic cavity (Hodge II -III) as many as 5 people (50\%).

Table. 4

The results of the Paired Sample Statistics analysis before and after the Implementation of Gym Ball on Third Trimester Primigravida Mothers

\begin{tabular}{lrr|r|r}
\hline \multicolumn{1}{c}{ Lower Fetal Decline } & \multicolumn{1}{c}{ Mean } & N & Std. Deviation & Std. Error Mean \\
\hline $\begin{array}{l}\text { Before the Implementation } \\
\text { of Gymball }\end{array}$ &, 00 & 10 &, 000 &, 000 \\
\hline $\begin{array}{l}\text { After the Implementation } \\
\text { of Gymball }\end{array}$ & 1,30 & 10 &, 823 &, 260 \\
\hline
\end{tabular}

Table. 4 shows that the average decrease in the lower part of the fetus before and after giving the gym ball technique is $1 / 5$ of the lower part of the fetus entering the pelvis.

Table 5

Paired Sample Correlation Analysis Results before and after Implementation of Gymball for Mothers of Third Trimester Primigravida

\begin{tabular}{|c|c|c|c|}
\hline Lower Fetal Decline & N & Correlation & Sig. \\
\hline Before \&After & 10 &, 812 &, 005 \\
\hline
\end{tabular}

Table. 5 shows that the correlation of the decrease in the lower part of the fetus is 0.8 which indicates a very strong and positive relationship and has a significant level at the $<0.05$ level, meaning that it is strongly related to birth weight $<2500$ grams as many as 16 toddlers $(27.1 \%)$.

2. Bivariate Analysis

Table.6

The Effect of Gymball Techniques on Lowering the Fetus

In Third Trimester Primigravida Mothers

\begin{tabular}{|c|c|c|c|c|c|c|c|c|}
\hline & \multicolumn{5}{|c|}{ Paired Differences } & \multirow[b]{3}{*}{ 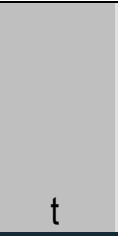 } & \multirow[b]{3}{*}{ df } & \multirow{3}{*}{$\begin{array}{l}\text { Sig. (2- } \\
\text { tailed) }\end{array}$} \\
\hline & \multirow[b]{2}{*}{ Mean } & \multirow{2}{*}{$\begin{array}{c}\text { Std. } \\
\text { Deviation }\end{array}$} & \multirow{2}{*}{$\begin{array}{l}\text { Std. } \\
\text { Error } \\
\text { Mean }\end{array}$} & \multicolumn{2}{|c|}{$\begin{array}{c}95 \% \text { Confidence Interval } \\
\text { of the Difference }\end{array}$} & & & \\
\hline & & & & Lower & Upper & & & \\
\hline $\begin{array}{l}\text { wer Fetal Decline } \\
\text { fore and After }\end{array}$ &,- 1.300 & 823 & ,260 & $-1,889$ &,- 711 & $-4,993$ & 9 & 001 \\
\hline
\end{tabular}


Table. 6 shows that the results of the hypothesis test show the value of sig $(-2$ tailed $)=0.001$ so that 0.001 $<0.05$ means that there is a significant effect before and after giving the gym ball technique to the decrease in the lower part of the fetus.

\section{DISCUSSION}

Based on research data regarding the decrease in the lower part of the fetus before giving the gym ball technique, all 10 pregnant women (100\%) have not entered the PAP. While the decrease in the lower part of the fetus after giving the gym ball technique, data obtained as many as 2 people $(20 \%)$ have not entered the PAP, 3 people $(30 \%)$ the lowest part of the fetus has entered the pelvis (Hodge I-II) and the lowest part of the fetus has entered the pelvis (Hodge I-II). II-III) as many as 5 people (30\%). The average decrease in the lower part of the fetus before and after the implementation of gym ball which was carried out $2 x$ in 4 weeks, namely there was a decrease of $1 / 5$ to $2 / 5$ the lowest part of the fetus had entered the pelvis. This shows that the mother sitting on the ball and rocking makes a sense of comfort and helps lower the baby's head using gravity while increasing the release of endorphins because the elasticity and curvature of the ball stimulate the receptors in the pelvis that are responsible for secreting endorphins.

Based on the results of statistical tests, the results obtained a significance value of $p$-value of 0.001 . This means that the $p$-value $(0.001)<0.05$, then $\mathrm{Ho}$ is rejected. This shows that there is a significant effect before and after giving the gym ball technique to the decrease in the lower part of the fetus in third-trimester primigravida mothers.

The head of the fetus that has entered the pelvic inlet is a sign of the onset of labor. Generally, the fetal head enters the pelvic inlet (PAP) at the end of gestation. In primigravida, the fetal head enters the pelvic inlet at 36 weeks of gestation. According to Konar (2015), the entry of the fetal head in the pelvic inlet occurs at 38 weeks of gestation. After the inclusion of the fetal head on the PAP, labor is expected to begin 2-3 weeks. Based on the traditional concept, in primigravida, the entry of the fetal head into the pelvic cavity occurs at 38 weeks of gestation. However, it is not following a clinical practice. In general, the entry of the fetal head into the pelvis occurs between 38-42 weeks or even during the first stage of labor (Sihotang, 2021).

According to Kurniawati (2017), a gym ball is a physical therapy ball that helps pregnant women in lowering the baby's head that can be used in various positions. One of the movements is by sitting on the ball and rocking to make a sense of comfort and help lower the baby's head using gravity while increasing the release of endorphins because the elasticity and curvature of the ball stimulate the receptors in the pelvis that are responsible for secreting endorphins. Other benefits that can be felt by mothers are reducing anxiety and helping the process of lowering the head and increasing maternal satisfaction and well-being (Kurniawati et al., 2017).

With the ball on the floor or in bed, the mother can kneel and bend over with her weight on the ball, pushing the pelvis up and helping the baby to turn into the correct position (back of the head position) thereby allowing faster labor progress. The birth ball helps the mother to stay in a standing position and also opens the pelvis, encouraging the baby to move downwards. Changing positions during labor will change the shape and size of the pelvis which will help the baby's head move to an optimal position during the first stage of labor and help the baby to rotate (Siregar et al., 2021).

Research conducted in India by Sharma and Soni (1978), and Gosh and Chaudharin (1980) found that 50\% and $43.4 \%$ of primigravida with involvement of the fetal head in the pelvis was a sign of impending labor. This study was based on a prospective study of 176 randomly selected primigravida who performed antenatal clinic visits at Neyveli General Hospital, India. However, only 27 primigravidas from 36 to 42 weeks gestation with first head involvement were reported in the study. The results showed that at 34 and 35 weeks of gestation there was no reported data on the entry of the fetal head into the PAP and pelvic cavity, while at 36 weeks of gestation there were found the number of primigravida with the fetal head entering the PAP and pelvic cavity as much as 1 person and the 
prevalence was $3.70 \%$. and obtained the highest number of primigravida with fetal head entering the PAP and pelvic cavity as many as 8 people with a prevalence of $29.63 \%$ occurring at 40 weeks of gestation (Sihotang, 2021).

Research conducted by Purwati (2020) shows that of the 16 respondents before giving treatment using the birth ball technique, almost all 11 people (69\%) experienced a decrease in the lower part of the fetus in Hodge II and a small proportion of respondents as many as 1 person $(6 \%)$ in Hodge I. Meanwhile, after giving treatment using the birth ball technique, almost all 10 people (63\%) experienced a decrease in the lower part of the fetus in Hodge III and a small number of respondents as many as 6 people (37\%) at Hodge IV (Purwati, 2020).

According to Aprilia's theory (2017) in the labor process, the ball (birthing ball) can be a medium/tool to be used in various positions. Sitting on a ball while pushing like a swing or making pelvic rotational movements can help lower the fetus into the pelvic floor. The ball provides support to the perineum without too much pressure and helps speed up the delivery process. In addition, the advantage of sitting upright on the ball can increase blood flow to the uterus, placenta, and baby, this posture makes the force of gravity push the baby's head down (Aprilia, 2017).

According to Sutisna (2021) research on the effect of gym ball guidance on labor progress in first-stage primigravida maternity at the Mother and Child Friends Primary Clinic, Bandung City in 2020, it was found that the group who did not receive gym ball guidance had average progress of 25 people. delivery of 254 minutes with a standard deviation of 123,477 minutes. Meanwhile, in the group that was given gym ball guidance, 25 people experienced an average of 150 minutes of labor progress, so there was an effect of gymball guidance on the progress of labor for primigravida mothers in the first stage of the active phase.(Sutisna, 2021)

The results of Catur, ES C (2017) research on the effect of pelvic rocking on the decline of the fetus in the active phase of the first stage of labor in primigravida that obtained as many as 11 mothers (23.9\%) who underwent pelvic rocking experienced a decrease in the fetal head station 0 . Meanwhile, mothers who received care standards experienced a decrease in fetal head station $<0$ as many as 14 mothers $(30.4 \%)$. when viewed from the number of frequencies, the group that was given pelvic rocking intervention was $4.3 \%$ greater than the control group in the lowering of the fetal head at station 0 (Catur ES., 2017).

Based on the results of research analysis shows that in the process of descending the lower part of the fetus, the ball can be an important tool and can be used in various positions. Sitting upright on the ball while pushing, such as swinging or making pelvic rotations, can help with the descent of the fetus. The ball provides support to the perineum without too much pressure and helps keep the fetus aligned in the pelvis. The sitting position on the ball is assumed to be similar to squatting to open the pelvis so that the presence of gravity will help the baby's head to descend optimally.

\section{CONCLUSIONS AND SUGGESTIONS}

The results showed that there was an effect of the gym ball technique on the decrease in the lower part of the fetus in third-trimester primigravida mothers with a value of sig $(-2$ tailed $)=0.001<0.05$. One of the good and safe exercise options for pregnant women is to improve physical health, reduce anxiety and help the process of lowering the head by doing gym ball technique exercises.

\section{REFERENCE}

Aprillia, Yessie. (2017). Gentle Birth Balance : Persalinan Holistik mind, Body and Soul. Bandung : Qanita

Catur ES. (2017). Efektifitas pelvic rocking terhadap lama persalinan, dilatasi servik dan penurunan kepala janin pada ibu primigravida. Prosiding Seminar Nasional Kebidanan, 007, 31-225. https://adoc.tips/download/efektifitas-pelvic-rocking-terhadap-lama-persalinan-dilatasi.html

Darma, I. Y., \& Abdillah, N. (2020). Penerapan Teknik Active Birth Menggunakan Birth Ball terhadap Kemajuan Persalinan Kala I Pada Ibu Bersalin. International Journal Of Community Medicine And Public Health, 7(12), 4745. https://jik.stikesalifah.ac.id/index.php/jurnalkes/article/view/335. 
Kurniawati, A., Dasuki, D., \& Kartini, F. (2017). Efektivitas Latihan Birth Ball Terhadap Penurunan Nyeri Persalinan Kala I Fase Aktif pada Primigravida. Jurnal Ners Dan Kebidanan Indonesia, 5(1), 1. https://doi.org/10.21927/jnki.2017.5(1).1-10, https://ejournal.almaata.ac.id/index.php/JNKI/article/view/341

Prawirohardjo, Sarwono. (2018), Ilmu Kebidanan. Jakarta: PT Bina Pustaka Sarwono.

Purwati, A. (2020). PENGARUH TEKNIK BOLA PERSALINAN (Birthing Ball) TERHADAP PENURUNAN BAGIAN BAWAH JANIN PADA IBU PRIMIGRAVIDA INPARTU KALA I FASE AKTIF DI PMB IKE SRI KEC.

BULULAWANG KAB. MALANG. Journal of Islamic Medicine, 4(1), 40-45. https://doi.org/10.18860/jim.v4i1.8846, http://ejournal.uin-malang.ac.id/index.php/iim/article/view/8846.

Sihotang, I. darbiantoro. (2021). Prevalensi Turunnya Kepala Janin Pada Pintu Atas Panggul Pada Primigravida Usia Kehamilan 34-36 Minggu Suatu Telaah Sistematis. 19-24,32-36. http://repositori.usu.ac.id/handle/123456789/30906

Siregar, W. W., Anuhgera, D. E., Hidayat, S., Maharani, S., Rohana, J., Tjut, U., \& Dhien, N. (2021). Pengaruh Pelaksanaan Teknik Birth Ball. 3(1), 76-83. http://ejournal.delihusada.ac.id/index.php/JPK2R/article/view/426.

Sutisna, E. H. (2021). Pengaruh Bimbingan Gym Ball Terhadap Kemajuan Persalinan Ibu Primigravida. Jurnal Asuhan Ibu Dan Anak, 6(2), 83-90. https://doi.org/10.33867/jaia.v6i2.266. https://journal.unisabandung.ac.id/index.php/jaia/article/download/266/151/.

Triana Indrayani, S.ST., M. K., \& Riyanti, S. M. (2019). Pengaruh Penggunaan Birthing Ball Terrhadap Penurunan Skor Nyeri Pada Ibu Bersalin Kala I Fase Aktif. Jakhkj, 5(1), 1-8. http://ejurnal.husadakaryajaya.ac.id/index.php/JAKHKJ/article/view/102 